\title{
Selective Cathodic Cleavage of Unsymmetrical Imidodicarbonates, Acylcarbamates and Diacylamides
}

\author{
Hernani L. S. Maia, ${ }^{* a}$ Luís S. Monteiro, ${ }^{a}$ Fredrik Degerbeck, ${ }^{b}$ Leif Grehn $^{b}$ and UIf Ragnarsson ${ }^{b}$ \\ a Departamento de Química, Universisade do Minho, Largo do Paço, 4719 Braga Codex, Portugal \\ b Department of Biochemistry, University of Uppsala, Biomedical Center, Box 576, S-751 23 Uppsala, \\ Sweden
}

\begin{abstract}
A study of the selective cathodic cleavage of one of the alkoxycarbonyl or acyl groups from various imidodicarbonates, acylamides, and diacylamides is reported. The compounds investigated include all 15 possible combinations of the following groups in unsymmetrical $N, N$-diprotected derivatives of benzylamine: $p$-nitrobenzyloxycarbonyl, trichloroethyloxycarbonyl, toluene-p-sulfonyl, benzoyl, benzyloxycarbonyl, and tert-butyloxycarbonyl which can all be electrochemically cleavaged, except the last one. Initially the compounds were examined by cyclic voltammetry in order to measure the potentials associated with the cleavage of each group and afterwards they were electrolysed at constant potential in the presence of a proton donor. The following ranges in negative potential were recorded: $1.03-1.13 \vee\left[Z\left(\mathrm{NO}_{2}\right)\right], 1.8-2.14 \vee$ (Troc), $1.75-2.41 \mathrm{~V}$ (Tos), 1.88-2.52 $\mathrm{V}(\mathrm{Bz})$, and 2.83-2.9 $\mathrm{V}(\mathrm{Z})$, thus occasionally revealing a drastic effect of the auxiliary group. In the electrolytic experiments competitive attack by base occasionally led to mixtures of monoacylamides. However, all compounds apart from some of the trichloroethyloxycarbonyl derivatives could be selectively cleaved in $89-100 \%$ yields when an appropriate proton donor was used. Tentative explanations are given for the behaviour of the compounds studied and some conclusions are drawn.
\end{abstract}

\begin{abstract}
Monoalkylation of the potassium salt of phthalimide followed by cleavage of the phthaloyl group is a general method developed by Gabriel in the last century for the synthesis of primary amines. ${ }^{1}$ Much later Sugasawa and $\mathrm{Abe}^{2}$ used the potassium salt of saccharin as a substitute for this reagent. As the corresponding analogues of saccharin were unsymmetrical, they could be selectively cleaved at the carbonyl group and alkylated again to yield $N, N$-dialkylamides, these leading to secondary amines after complete deprotection. More recently, several unsymmetrical imidodicarbonates were developed and used in Gabriel and Mitsunobu reactions, mainly in the fields of polyamines and amino acids. ${ }^{3}$ These novel reagents are of the type $\mathrm{P}^{1} \mathbf{P}^{2} \mathrm{NH}$ (1) and, as for the saccharin derivatives, their principal advantage over phthalimide derives from the fact that, after alkylation, selective cleavage of one $\left(\mathrm{P}^{1}\right)$ of the monovalent protecting groups instead of the divalent phthaloyl group leads to a product, which can again be monoalkylated. After removal of the second protecting group, secondary instead of primary amines can thus be obtained. The usefulness of these com-

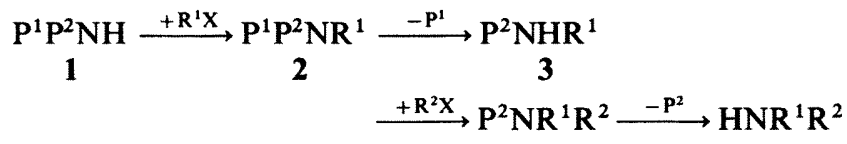

pounds depends essentially on how selectively the cleavage of the protecting groups can be performed from the title compounds 2 , from here on simply referred to as diacylamides.

The well known tendency of $\mathrm{N}$-alkylphthalimides to undergo base-catalysed hydrolysis leading to partial cleavage of this group seems to be enhanced in the above mentioned alkyl derivatives of saccharin. This enhancement is probably due to an increased electron-withdrawing effect related to the sulfonyl group and, as a result, alkaline hydrolysis could be used in the latter context. ${ }^{2}$ Similarly, some of the above diacylamides 2 readily undergo base-catalysed nucleophilic attack to yield the partially deprotected derivatives $\mathrm{P}^{2} \mathrm{NHR}{ }^{3}$ In fact, high yield cleavages of formyl, acetyl, and benzoyl (Bz) groups were obtained both by aminolysis and by alcoholysis of the corresponding Boc (tert-butoxycarbonyl) anilides $\left(\mathrm{P}^{2}=\right.$ Boc, $\mathrm{R}=$ $\mathrm{Ph}){ }^{4}$ The benzyloxycarbonyl $(\mathrm{Z})$ group was also cleaved in a similar way with a good selectivity ${ }^{5}$ but not the toluene-psulfonyl (Tos) group and a few others. ${ }^{4}$ Nevertheless, we have shown that these can still be removed selectively from the corresponding Boc-anilides by cathodic reduction ${ }^{6}$ in dilute and/or concentrated solution to give tert-butyl $N$-phenylcarbamate, usually in high yield. Furthermore, a recent study dealing with the electrochemical detosylation of $N$-tos- $\beta$-lactam derivatives has shown that the tosyl function could be easily removed by cathodic reduction without concomitant cleavage of the sensitive lactam moiety. ${ }^{7}$ As expected, also in this case the cleavage potential was considerably shifted by the electronwithdrawing influence of the ring carbonyl group.

The above investigations clearly indicate that this double protection strategy offers promising possibilities in a wide range of synthetic work with various double-protected amines. In order to explore further the scope of this approach with respect to potential practical applications we have now investigated the cathodic behaviour of all combinations of the following acyl groups in unsymmetrical $N, N$-diprotected derivatives of benzylamine ( $2, \mathbf{R}^{1}=$ benzyl): $\mathbf{P}^{1}, \mathbf{P}^{2}=\mathrm{Z}\left(\mathrm{NO}_{2}\right)$ ( $p$-nitrobenzyloxycarbonyl), Troc (trichloroethyloxycarbonyl), Tos, $\mathrm{Bz}, \mathrm{Z}$ and Boc.

\section{Results}

Synthesis of Substrates and Precursors.-The Boc-acylamides $(2 a, b)$ were synthesized by treatment of the parent monoacylamides with (Boc) ${ }_{2} \mathrm{O}$ in the presence of catalytic amounts of dimethylaminopyridine (DMAP). The Tos-acylamides (2c-f)

$$
\begin{gathered}
\mathrm{P}^{1} \mathrm{NHBzl}+(\mathrm{Boc})_{2} \mathrm{O} \stackrel{\text { DMAP }}{\longrightarrow} \mathrm{P}^{1} \mathrm{~N}(\mathrm{Boc}) \mathrm{Bzl} \\
\mathbf{2 a}, \mathrm{P}^{1}=\text { Troc; } \mathbf{2 b}, \mathrm{P}^{1}=\mathrm{Z}^{1}\left(\mathrm{NO}_{2}\right)
\end{gathered}
$$


Table 1 Peak potentials $(-E / \mathrm{V})$ obtained by cyclic voltammetry of compounds of the type $\mathrm{P}^{1} \mathrm{P}^{2} \mathrm{NBzl}\left(2,0.005 \mathrm{~mol} \mathrm{dm}^{-3}\right)$ in dimethylformamide with $\mathrm{Et}_{4} \mathrm{NCl}$ or $\mathrm{Bu}_{4} \mathrm{NBF}_{4}{ }^{a}\left(0.1 \mathrm{~mol} \mathrm{dm}{ }^{-3}\right)$ as the supporting electrolyte

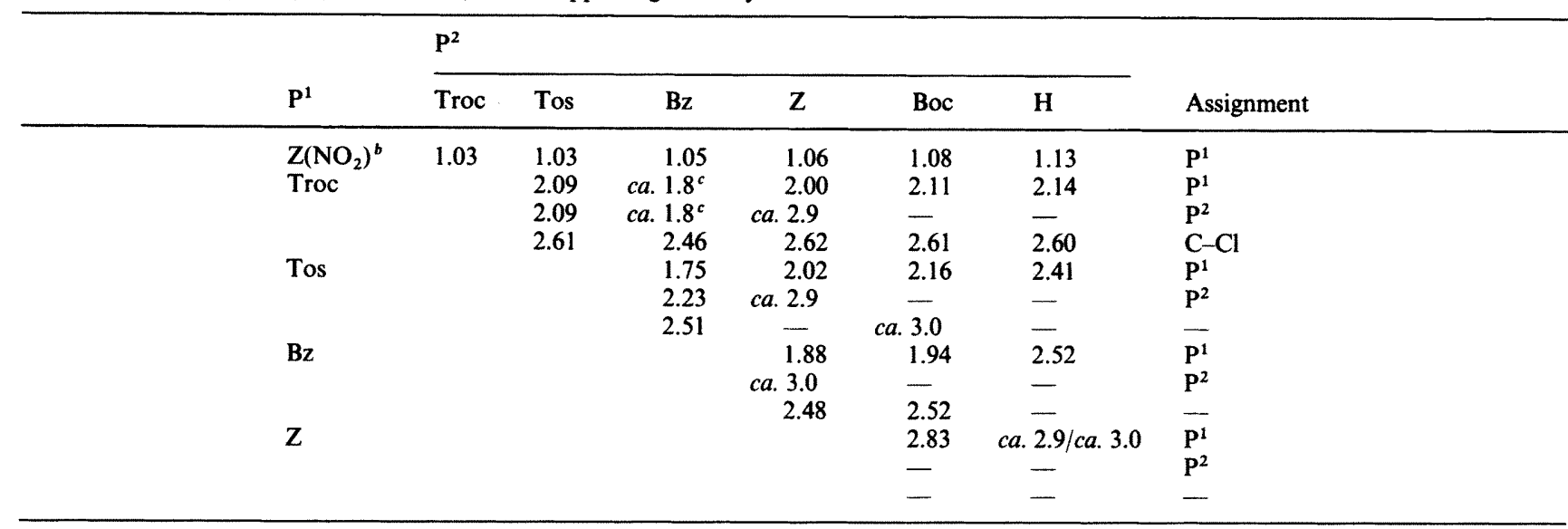

${ }^{a} \mathrm{Bu}_{4} \mathrm{NBF}_{4}$ was used only with the $\mathrm{Z}$ derivatives. ${ }^{b}$ The cyclic voltammogram for the $\mathrm{NO}_{2}$ group always shows various peaks which in this case overlap with those corresponding to the other groups, thus making the assignments difficult. ${ }^{c}$ Owing to overlap of peaks these results are not accurate.

Table 2 Effect of $\mathrm{P}^{2}$ on the peak potential of $\mathrm{P}^{1}\left(\Delta E_{\mathrm{P}^{1}} / \mathrm{V}\right)^{a}$ in compounds of the type $\mathrm{P}^{1} \mathrm{P}^{2} \mathrm{NBzl}(2)$ as calculated from Table 1

\begin{tabular}{llllll}
\hline & \multicolumn{3}{l}{$\mathrm{P}^{2}$} \\
\cline { 2 - 6 } $\mathrm{P}^{1}$ & Troc & Tos & $\mathrm{Bz}$ & $\mathrm{Z}$ & $\mathrm{Boc}$ \\
\hline $\mathrm{Z}\left(\mathrm{NO}_{2}\right)$ & 0.10 & 0.10 & 0.08 & 0.07 & 0.05 \\
Troc & - & 0.05 & $0.3^{b}$ & 0.14 & 0.03 \\
Tos & 0.32 & - & 0.66 & 0.39 & 0.25 \\
$\mathrm{Bz}$ & $0.7^{b}$ & 0.29 & - & 0.64 & 0.58 \\
$\mathrm{Z}$ & $0.1^{b}$ & $0.1^{b}$ & $0.0^{b}$ & - & $0.2^{b}$
\end{tabular}

${ }^{a} \Delta E_{\mathrm{p}^{1}}$ is the difference between $E_{\mathrm{P}^{1}}$ for $\mathrm{P}^{1} \mathrm{P}^{2} \mathrm{NBzl}$ and $E_{\mathrm{p}^{1}}^{\prime}$ for $\mathrm{P}^{1} \mathrm{NHBzl}: \Delta E_{\mathrm{P}^{1}}=E_{\mathrm{P}^{1}}-E_{\mathrm{p}^{1}}^{\prime}{ }^{b}$ Owing to overlap of peaks this result is not accurate.

were prepared by acylation of $N$-benzyltosylamide, also in the presence of DMAP. All other diacylamides $(2 g-1)$ were obtained by alkylation of the appropriate Gabriel reagent with benzyl

$$
\mathrm{P}^{2}-\mathrm{Cl}+\operatorname{TosNHBzl} \stackrel{\text { DMAP }}{\longrightarrow} \underset{2}{\operatorname{Tos} N\left(\mathrm{P}^{2}\right) \mathrm{Bzl}}
$$

2c, $\mathrm{P}^{2}=\mathrm{Bz} ; \mathbf{2 d}, \mathrm{P}^{2}=$ Troc; $2 \mathrm{e}, \mathrm{P}^{2}=\mathrm{Z} ; \mathbf{2 f}, \mathrm{P}^{2}=\mathrm{Z}\left(\mathrm{NO}_{2}\right)$

alcohol in the presence of diethyl azodicarboxylate (DEAD)

$$
\underset{\mathbf{P}}{\mathrm{P}^{1} \mathrm{P}^{2} \mathrm{NH}}+\mathrm{PhCH}_{2} \mathrm{OH} \underset{\mathrm{DEAD}}{\stackrel{\mathrm{Ph}_{3} \mathrm{P}}{\longrightarrow}} \mathrm{P}^{1} \mathbf{P}^{2} \mathrm{NBzl}
$$

$\mathbf{2 g}, \mathrm{P}^{1}=\mathrm{Bz}, \mathrm{P}^{2}=\mathrm{Z} ; \mathbf{2 h}, \mathrm{P}^{1}=\mathrm{Bz}, \mathrm{P}^{2}+$ Troc; $\mathbf{2 i}, \mathbf{P}^{1}=$ Troc, $\mathbf{P}^{2}=Z ; 2 \mathbf{j}, \mathbf{P}^{1}=\mathrm{Bz}, \mathrm{P}^{2}=\mathrm{Z}\left(\mathrm{NO}_{2}\right) ; \mathbf{2 k}, \mathbf{P}^{1}=$ Troc, $\mathbf{P}^{2}=$ $\mathrm{Z}\left(\mathrm{NO}_{2}\right) ; 2 \mathbf{2 l} \mathrm{P}^{1}=\mathrm{Z}, \mathrm{P}^{2}=\mathrm{Z}\left(\mathrm{NO}_{2}\right)$

and triphenylphosphine (Mitsunobu reaction). ${ }^{3}$ The Gabriel reagents $(1 \mathrm{a}-\mathrm{e})$ were synthesized by reaction of isocyanate with the appropriate alcohol.

$$
\mathrm{P}^{1}-\mathrm{N}=\mathrm{C}=\mathrm{O}+\mathrm{ROH} \longrightarrow \mathrm{P}^{1} \mathrm{P}^{2} \mathrm{NH}_{1} \quad\left(\mathrm{P}^{2}=\mathrm{ROCO}\right)
$$

1a, $\mathrm{P}^{1^{\bullet}}=\operatorname{Tos}, \mathrm{P}^{2}=\mathrm{Z} ; \mathbf{1 b}, \mathrm{P}^{\mathbf{1}^{\bullet}}=\mathrm{Bz}, \mathrm{P}^{2}=$ Troc; $\mathbf{1 c}, \mathrm{P}^{1^{\bullet}}=\mathrm{Bz}$, $\mathrm{P}^{2}=\mathrm{Z}\left(\mathrm{NO}_{2}\right) ; \mathbf{1 d}, \mathrm{P}^{1 \cdot}=$ Troc, $\mathrm{P}^{2}=\mathrm{Z}\left(\mathrm{NO}_{2}\right)$

The above compounds and also the corresponding monoacyl derivatives $\left(\mathrm{P}^{1} \mathrm{NHCH}_{2} \mathrm{Ph}\right.$ or $\left.\mathbf{P}^{2} \mathrm{NHCH}_{2} \mathrm{Ph}\right)$ were characterized by cyclic voltammetry and electrolysis. Preparative electrolyses were then carried out on all compounds under different experimental conditions in order to optimise the yields of selectively cleaved material. Particular attention was paid to the effect of an added proton donor.

Cyclic Voltammetry Experiments and Voltammogram Assignments.-All experiments were carried out at a vitreous carbon electrode in the absence of any added proton donor. The $\mathrm{Z}\left(\mathrm{NO}_{2}\right)$ derivatives showed a complex pattern of cathodic peaks, the first of them exhibiting an associated anodic peak within the time scale of the experiments. ${ }^{8}$ All the other compounds except BocNHBzl exhibited one or more (up to three) reduction peaks within the range of potentials scanned, all corresponding to irreversible processes. Assignment of the first reduction peak of the cyclic voltammograms was carried out by electrolysing each compound at a potential slightly more negative than that corresponding to this peak, as described below, and identifying the product by HPLC. The corresponding acyl group was thus labelled as $\mathrm{P}^{1}$. The next peak was assigned to $\mathrm{P}^{2}$, bearing in mind our previous experience with diacylamides ${ }^{6}$ showing that the potential required to place an electron on one of their acyl groups would be less negative than that required by the same group in the corresponding monoacyl derivatives $\mathbf{P}^{2} \mathrm{NHBzl}$. When a third peak was found before saturation it was also registered but assigned only in the case of the Troc derivatives where we tentatively relate it to cleavage of a $\mathrm{C}-\mathrm{Cl}$ bond. Therefore, in Table 1 up to three values are presented for each compound, viz. the potentials $E_{\mathrm{p}^{1}}$ and $E_{\mathrm{p}^{2}}$ at which $\mathbf{P}^{1}$ and $\mathbf{P}^{2}$ received an electron, respectively, and a third potential usually not assigned. In the $\mathrm{Z}\left(\mathrm{NO}_{2}\right)$ compounds the first reduction peak was also assigned to $\mathrm{P}^{1}$ but, owing to the complexity of the pattern observed in their voltammograms, no attempt was made to assign the other peaks. The potential required to place an electron on the benzyl group of $\mathrm{Z}$ is so low that the values presented for this group are fairly inaccurate owing to overlap with peaks due to the supporting electrolyte and/or the solvent. In Table 2 the effect of $\mathrm{P}^{2}$ on the peak potential of $\mathrm{P}^{1}\left(\Delta E_{\mathrm{P}^{1}}\right)$ in compounds of the type $\mathrm{P}^{1} \mathrm{P}^{2} \mathrm{NBzl}$ is presented together with the corresponding shifts related to $\mathrm{P}^{2}$ $\left(\Delta E_{\mathrm{p}^{2}}\right)$, as calculated from Table 1 .

Electrolyses.-The diacylamides were electrolysed in acetonitrile containing $\mathrm{Et}_{4} \mathrm{NCl}$ as the supporting electrolyte. Both methanol and $\mathrm{Et}_{3} \mathrm{NHCl}$ were used as proton donors in all cases, thus allowing evaluation of the effect of the respective conjugated bases (methoxide and triethylamine) on the selectivity of the cleavage. The reactions were carried out at a 
Table 3 Yields (\%) of $\mathrm{P}^{2} \mathrm{NHBzl}$ and $\mathrm{P}^{1} \mathrm{HNBzl}(3)$, respectively, in the cleavage of compounds of the type $\mathrm{P}^{1} \mathrm{P}^{2} \mathrm{NBzl}$ (2) as determined by HPLC

\begin{tabular}{|c|c|c|c|c|c|c|}
\hline \multirow[b]{2}{*}{$\mathbf{P}^{1}$} & \multicolumn{5}{|l|}{$\mathbf{P}^{2}$} & \multirow{2}{*}{$\begin{array}{l}\text { Proton } \\
\text { donor }^{a}\end{array}$} \\
\hline & Troc & Tos & Bz & Z & Boc & \\
\hline \multirow[t]{2}{*}{$\mathrm{Z}\left(\mathrm{NO}_{2}\right)$} & $45 / 41$ & $100 / 0$ & $66 / 11$ & $69 / 0$ & $65 / 0$ & $\mathrm{MeOH}$ \\
\hline & $84 / 0$ & $99 / 0$ & $94 / 4$ & $92 / 5$ & $90 / 0$ & $\mathrm{Et}_{3} \mathrm{NHCl}$ \\
\hline \multirow[t]{2}{*}{ Troc } & & $90 / 0$ & $46 / 0$ & $65 / 0$ & $63 / 0$ & $\mathrm{MeOH}$ \\
\hline & & $64 / 0$ & $54 / 0$ & $72 / 0$ & $85 / 0$ & $\mathrm{Et}_{3} \mathrm{NHCl}$ \\
\hline \multirow[t]{2}{*}{ Tos } & & & $55 / 45$ & $74 / 26$ & $78 / 18$ & $\mathrm{MeOH}$ \\
\hline & & & $90 / 0$ & $100 / 0$ & $96 / 0$ & $\mathrm{Et}_{3} \mathrm{NHCl}$ \\
\hline \multirow[t]{2}{*}{$\mathrm{Bz}$} & & & & $68 / 32$ & $100 / 0$ & $\mathrm{MeOH}$ \\
\hline & & & & $91 / 5$ & $89 / 0$ & $\mathrm{Et}_{3} \mathrm{NHCl}$ \\
\hline \multirow[t]{2}{*}{ Z } & & & & & $91 / 0$ & $\mathrm{MeOH}$ \\
\hline & & & & & $97 / 0$ & $\mathrm{Et}_{3} \mathrm{NHCl}$ \\
\hline
\end{tabular}

${ }^{a}$ Concentrations: substrate, $0.005 \mathrm{~mol} \mathrm{dm}^{-3} ; \mathrm{Et}_{4} \mathrm{NCl}, 0.1 \mathrm{~mol} \mathrm{dm}{ }^{-3}$; $\mathrm{MeOH}, 2 \% ; \mathrm{Et}_{3} \mathrm{NHCl}, 0.015 \mathrm{~mol} \mathrm{dm}^{-3}$.

constant potential $20-50 \mathrm{mV}$ more negative than that corresponding to the first peak of the corresponding voltammogram, as indicated in Table 1, monitored by HPLC and stopped when most or all the starting material had been consumed. The yields of monoacylamides $\left(\mathrm{P}^{2} \mathrm{NHCH}_{2} \mathrm{Ph}\right.$ and $\left.\mathrm{P}^{1} \mathrm{NHCH}_{2} \mathrm{Ph}\right)$ are presented in Table 3.

\section{Discussion}

Cyclic Voltammetry Results. - In agreement with our previous experience, ${ }^{6}$ Table 1 shows that cathodic cleavage of an acyl group $\mathrm{P}^{1}$ in diacylamides $\mathrm{P}^{1} \mathrm{P}^{2} \mathrm{NBzl}$ requires a less negative potential than that necessary to cleave the same group in the corresponding monoacyl derivatives $\mathrm{P}^{1} \mathrm{NHBzl}$. This shift $\left(\Delta E_{\mathrm{P}^{1}}\right)$ in the potential is assigned to a polarizing effect of the second acyl group $\left(\mathrm{P}^{2}\right)$, thus increasing the electron affinity of $\mathrm{P}^{1}$ in the former compounds as compared with the latter. Table 2 summarizes such shifts together with similar shifts related to $\mathrm{P}^{2}\left(\Delta E_{\mathrm{P}^{2}}\right)$, all calculated from Table 1; the latter have no practical value with regard to cleavage of the corresponding compounds but are useful for evaluation of the polarizability of each acyl group $\mathrm{P}^{2}$ and also of the polarizing capacity of the group $\mathrm{P}^{1}$ associated with it in the diacylamide. We have reported ${ }^{9}$ that the cyclic voltammogram of benzyl $N$-alkylcarbamates exhibits two peaks separated by approximately $0.1 \mathrm{~V}$ but that cleavage of these compounds can be carried out at the potential of the first peak. Accordingly, two peaks were now found for $\mathrm{ZNHBzl}(-2.9$ and $-3.0 \mathrm{~V}$ as shown in Table 1$)$ but only the first was used in the calculation of the shifts $\Delta E_{\mathrm{P}}$ for compounds with $\mathrm{Z}$.

Comparison between the various lines of Table 2 shows that the cleavage potentials for urethane-type protecting groups, viz. $\mathrm{Z}\left(\mathrm{NO}_{2}\right)$, Troc and $\mathrm{Z}$, are little affected by any neighbouring acyl group as compared with Tos and $\mathrm{Bz}$ (nevertheless, the shifts related to $\mathrm{Bz}$ are almost double those found for Tos). This behaviour may be due to lack of conjugation of the electrondeficient centre with the polarizing group, e.g. $\mathrm{CH}_{2} \mathrm{C}_{6} \mathrm{H}_{4} \mathrm{NO}_{2}$ and $\mathrm{C}_{6} \mathrm{H}_{5}$, respectively, in $\mathrm{Z}\left(\mathrm{NO}_{2}\right) \mathrm{N}(\mathrm{Bz}) \mathrm{Bzl}^{6}$

Comparison between the columns of Table 2 reveals that some groups are better polarizers than others. This is well illustrated by the case of Boc which appears to be a somewhat weaker polarizer than $Z$ or Troc. In order to explain the above shifts it seems reasonable to assume that the polarization caused by a given acyl group should be influenced by its electronwithdrawing effect. The above difference between Boc and the other urethane-type groups should be due to partial inhibition of the electron-withdrawing effect of $\mathrm{P}^{2}$ by electron-release of $\mathrm{Bu}$ O in Boc as compared with $\mathrm{PhCH}_{2} \mathrm{O}$ and $\mathrm{Cl}_{3} \mathrm{CCH}_{2} \mathrm{O}$ in $\mathrm{Z}$ and Troc, respectively. $\mathrm{Bz}$ is the most efficient polarizer of the groups studied, possibly owing to enhancement of the electronwithdrawing effect of the carbonyl group by the aromatic ring. Unexpectedly, however, Tos seems to be a poor polarizer. Table 2 shows that, on the one hand, the shift caused by $Z$ or Boc on $\mathrm{Bz}(0.64$ and $0.58 \mathrm{~V}$, respectively) is twice that caused by Tos $(0.29 \mathrm{~V})$ and that, on the other hand, the shift caused by Bz on Tos $(0.66 \mathrm{~V})$ is in its turn roughly double those caused by $Z$ and $B o c(0.39$ and $0.25 \mathrm{~V}$, respectively). Thus, one may conclude that $\mathrm{Bz}$ and Tos are by far the best and the poorest polarizers, respectively, of all groups studied.

Advantage could be taken of the above properties for the selective cleavage of $\operatorname{Tos} N(\mathrm{Bz}) \mathrm{Bz}$. In fact, we have shown ${ }^{10}$ that when the difference in the cleavage potential for two groups in the same molecule is small, the selectivity of this reaction may be poor. From Table 1 it can be seen that the difference in the cleavage potential of Tos and $\mathrm{Bz}$ in monoacyl derivatives is only $0.11 \mathrm{~V}$. However, as $\mathrm{Bz}$ is a much better polarizer than Tos, this difference increases to $0.48 \mathrm{~V}$, despite the former group generally being more polarizable than the latter. Nevertheless, in other cases these polarizing effects may act in the reverse direction as in TrocN(Tos)Bzl and TrocN(Bz)Bzl. Differences of 0.27 and $0.38 \mathrm{~V}$, respectively, in cleavage potentials are found for the corresponding monoacyl derivatives, while in the diacylamides the two acyl groups in each compound receive an electron at approximately the same potential $(2.09 \mathrm{~V}$ in the former and $1.8 \mathrm{~V}$ in the latter).

Electrolyses. - The most noteworthy feature of the data of Table 3 is that when $\mathrm{Et}_{3} \mathrm{NHCl}$ is used as the proton donor instead of methanol the yields of the cleavage reactions are usually considerably increased. In most cases the use of methanol results in mixtures of the two corresponding monoacyl derivatives. Although all the groups tested except Boc can be cleaved by cathodic reduction, the formation of such mixtures can be explained only by competitive cleavage due to nucleophilic attack by base. In fact, despite being electrochemically stable, Boc is also partially cleaved in TosN(Boc)Bzl (further evidence of this competitivity will be given below). The use of $\mathrm{Et}_{3} \mathrm{NHCl}$ instead of methanol usually increases the selectivity of the reactions. This is well illustrated in the case of the $\mathrm{Z}\left(\mathrm{NO}_{2}\right)$ derivatives for which the yields usually increase up to $90 \%$, or more, when $\mathrm{Et}_{3} \mathrm{NHCl}$ is used instead of methanol. The combination of $\mathrm{Z}\left(\mathrm{NO}_{2}\right)$ with Troc is an exception and will be discussed below, together with the other Troc derivatives, where a possible explanation for this behaviour will be suggested.

The fairly high degree of selectivity obtained with the derivatives of $\mathrm{Z}\left(\mathrm{NO}_{2}\right)$ is understandable, as the potential required to cleave this group is far from that required to cleave the other groups. Similarly, as (i) the cleavage of $Z$ requires the most negative of all potentials measured and (ii) Boc is not cleavable by reduction, other combinations of these groups can be expected to lead to a fairly high selectivity in the cleavages as in fact is shown in Table 3. However, in the combinations Troc/Tos and Troc/Bz both acyl groups of the corresponding diacylamides cleave at the same potential but in these cases we were still able to obtain selective cleavage of Troc, although the yields were low, possibly owing to side reactions related to Troc. Despite $\mathrm{Bz}$ being more polarizable than Tos, the former is a much more powerful polarizer than the latter and, therefore, in the combination $\mathrm{Tos} / \mathrm{Bz}$ the difference in the potentials for cleavage of these groups is larger than it would be if no polarziation took place and, then, selective cleavage of Tos could be achieved in a good yield.

Although, as stated above, in TrocN(Tos)Bzl the same potential is required to place an electron on Troc and Tos, TrocNHBzl could not be identified as a reaction product (a similar situation was met in the combination of Troc with $\mathrm{Bz}$ ). 
When methanol was used as the proton donor the reaction took approximately one hour to completion and a fairly high selectivity was obtained. However, when $\mathrm{Et}_{3} \mathrm{NHCl}$ was substituted for methanol the reaction required five hours and the amount of TosNHBzl found decreased; again no TrocNHBzl was detected. This suggests that in the first instance Troc was cleaved mainly by electrogenerated bases. In fact, in an experiment with TrocN(Boc)Bzl the reaction proceeded even if the electricity source was switched off before completion. The low yields obtained in the slower reactions may be explained as resulting from decomposition of the deacylation product as it forms, this decomposition occurring by electrochemical cleavage of $\mathrm{C}-\mathrm{Cl}$ bonds as found by other authors. ${ }^{11,12} \mathrm{~A}$ similar decomposition of the starting material might also take place to give secondary products that would not be cleavable any more at the working potential, thus leading to considerably lower yields as was found with all Troc derivatives. Finally, analysis of the columns of Table 3 also shows that the Bz group seems to be more prone to base cleavage than $\mathrm{Z}$, whereas Boc appears essentially stable.

\section{Conclusions}

All compounds 2 investigated, except those having a Troc group, could be cleaved selectively to give the expected product 3 in yields in the range $89-100 \%$ when $\mathrm{Et}_{3} \mathrm{NHCl}$ was used as a proton donor. This product corresponded to the monoacyl derivative formed by cleavage of the acyl group that receives a proton at the least negative potential as observed by cyclic voltammetry. The nature of the proton donor seems to be crucial for the success of this approach, as the strong base generated during the cathodic processes will attack the most base labile groups, at least in the reagent, and render the process fairly unselective. This appeared to be enhanced in the case of the Troc group which may be a poor choice for electrochemical use; this behaviour may be due to possible competitive cleavage of $\mathrm{C}-\mathrm{Cl}$ bonds leading to lower yields of the required products.

The results obtained with regard to the behaviour of the various acyl groups in this investigation expand the scope of a strategy we have already examined. ${ }^{10}$ This is based on the exploitation of the polarizing effect of an acyl group, resulting in increased lability to cathodic cleavage of another similar group attached to the same nitrogen atom. For this strategy to be useful it is required that one of the acyl groups be stable (polarizer) and the other labile to cathodic cleavage. If both groups are labile to cathodic cleavage, then one should be sufficiently more labile than the other, i.e. the potential required to place an electron on one of the groups should be as different as possible from that required by the other group. Our results show that common urethane-type groups are fairly good polarizers but little influenced by other groups, owing to absence of conjugation between the electron-accepting moiety of the former and the polarizing moiety of the latter. This makes them good choices as polarizers in connection with polarizable groups such as $\mathrm{Bz}$ or Tos. Therefore, although $\mathrm{Bz}$ was the most powerful polarizer of all groups investigated, it is not a good choice as such as it was also the most polarizable group and thus prone to be largely influenced by the polarizer. Finally, our results set a few rules that may be useful for modification of conventional or development of new protecting groups appropriate for optimizing the efficiency of this strategy for selective deprotection

\section{Experimental}

General Procedures.-Analytical grade $\mathrm{Et}_{4} \mathrm{NCl}$ was used without further purification. $\mathrm{Et}_{3} \mathrm{NHCl}$ was prepared by adding dropwise a solution of hydrogen chloride (approximately $1 \mathrm{~mol} \mathrm{dm}^{-3}$ ) in diethyl ether to an equal amount of a solution of triethylamine with the same concentration, also in ether; the precipitate was filtered off, washed, dried, recrystallized from chloroform, and dried again. $\mathrm{Bu}_{4} \mathrm{NBF}_{4}$ was prepared by precipitation on mixing solutions of tetrabutylammonium bisulfate and sodium tetrafluoroborate followed by recrystallization of the product from ethanol/ water. Acetonitrile was purified by distillation from calcium hydride under nitrogen. DMF was stored over magnesium sulfate and then distilled from calcium hydride at reduced pressure. All HPLC experiments were run on a Shimadzu instrument, type $6 \mathrm{~A}$, connected to a Merck prepacked column, type Hibar RT 250-4, filled with LiChrospher $100 \mathrm{CH}-18 / 2$ (5 $\mu \mathrm{m})$ and the eluent was a mixture of acetonitrile and water. The peaks were measured with a Shimadzu integrator, type CR6A Chromatopack. TLC tests were carried out on Merck precoated, $0.25 \mathrm{~mm}$ thick, Kieselgel 60 plates and the spots were revealed by exposure to vapourized iodine or visualized with dicarboxidine. All new compounds gave satisfactory elemental analyses (CHN $\pm 0.2 \%$ ) except when otherwise stated.

Preparation of Materials.-The novel compounds used in this investigation were prepared by one of the methods described below. Yields, selected properties, and the method used are indicated in Tables 4 and 5. The following compounds were prepared according to procedures published elsewhere: $\mathrm{Z}\left(\mathrm{NO}_{2}\right) \mathrm{NHBzl}^{13}{ }^{13}$ TrocNHBzl, ${ }^{13,14}$ TosNHBzl, ${ }^{15} \mathrm{BzNHBzl}^{16}$ ZNHBzl, ${ }^{17}$ BocNHBzl, ${ }^{4}$ TrocNHZ, ${ }^{18}$ BzNHZ, ${ }^{19}$ TosN(Boc)$\mathrm{Bzl},{ }^{10} \mathrm{BzN}(\mathrm{Boc}) \mathrm{Bzl},{ }^{10} \mathrm{ZN}(\mathrm{Boc}) \mathrm{Bzl} .{ }^{19}$

Method A (compounds 1a-e). To ROH (1 eq.) in dry dichloromethane $\left(1 \mathrm{~mol} \mathrm{dm}^{-3}\right)$ a solution of $\mathrm{P}^{1}-\mathrm{N}=\mathrm{C}=\mathrm{O}(0.96$ eq. $)$ in dry dichloromethane $\left(0.96 \mathrm{~mol} \mathrm{dm}^{-3}\right)$ was added dropwise with stirring at $0^{\circ} \mathrm{C}$ under dry conditions. After stirring for another hour at $0^{\circ} \mathrm{C}$ and overnight at room temperature, the solvent was evaporated at reduced pressure and the residue thus obtained was triturated with an appropriate solvent (pentane, hexane, or light petroleum). Crystallization was induced by cooling to $-20^{\circ} \mathrm{C}$ and the precipitate collected by filtration. The yield of crude product obtained is shown in Table 4 and recrystallization was performed as indicated.

Method B (compounds 2a-b). $\mathbf{P}^{1}$ NHBzl (1 eq.) was dissolved in dry acetonitrile $\left(1 \mathrm{~mol} \mathrm{dm}^{-3}\right)$ and DMAP (0.1 eq.) and triethylamine (1.5 eq.) added. Then, a solution of (Boc) ${ }_{2} \mathrm{O}(1.1$ eq.) in dry acetonitrile $\left(2.2 \mathrm{~mol} \mathrm{dm}^{-3}\right)$ was added in one portion with rapid stirring. The mixture was stirred overnight and the solvent evaporated at reduced pressure. The residue was partitioned between $200 \mathrm{~cm}^{3}$ of diethyl ether and $100 \mathrm{~cm}^{3}$ of aqueous $\mathrm{KHSO}_{4}\left(1 \mathrm{~mol} \mathrm{dm}{ }^{-3}\right)$, and washed with $\mathrm{KHSO}_{4}(1 \mathrm{~mol}$ $\left.\mathrm{dm}^{-3}\right), \mathrm{NaHCO}_{3}\left(1 \mathrm{~mol} \mathrm{dm}{ }^{-3}\right)$, and brine $\left(3 \times 50 \mathrm{~cm}^{3}\right.$ each $)$. After drying over $\mathrm{MgSO}_{4}$ the extract was taken to dryness at reduced pressure to afford $\mathrm{P}^{1} \mathrm{~N}(\mathrm{Boc}) \mathrm{Bzl}$ in a yield as indicated in Table 5. Recrystallization was performed with the solvent indicated.

Method C (compounds $\mathbf{2 c - f}$ ). TosNHBzl (1 eq.) was dissolved in dry dichloromethane $\left(0.2 \mathrm{~mol} \mathrm{dm}{ }^{-3}\right)$ followed by addition of DMAP ( 0.1 eq.) and triethylamine ( 1.5 eq.). Then, $\mathrm{P}^{2} \mathrm{Cl}$ ( 1.5 eq.) was slowly added with cooling at $0^{\circ} \mathrm{C}$. The mixture was stirred overnight and the solvent evaporated at reduced pressure. The residue was then partitioned between $200 \mathrm{~cm}^{3}$ of diethyl ether and $100 \mathrm{~cm}^{3}$ of aqueous $\mathrm{KHSO}_{4}\left(1 \mathrm{~mol} \mathrm{dm}^{-3}\right)$, and washed with $\mathrm{KHSO}_{4}\left(1 \mathrm{~mol} \mathrm{dm}{ }^{-3}\right), \mathrm{NaHCO}_{3}\left(1 \mathrm{~mol} \mathrm{dm}^{-3}\right)$, and brine $\left(3 \times 50 \mathrm{~cm}^{3}\right.$ each). After drying $\left(\mathrm{MgSO}_{4}\right)$ the extract was taken to dryness at reduced pressure to afford $\operatorname{Tos} \mathrm{N}\left(\mathrm{P}^{2}\right) \mathrm{Bzl}$ in a yield as indicated in Table 5. Recrystallization was performed with the solvent indicated. 
Table 4 Selected properties of novel compounds: Gabriel reagents (1a-d)

\begin{tabular}{|c|c|c|c|c|c|c|}
\hline $\begin{array}{l}\text { Compound } \\
\text { formula/no. }\end{array}$ & $\begin{array}{l}\text { Method of } \\
\text { preparation }\end{array}$ & $\begin{array}{l}\text { Compound } \\
\text { (M.W.) }\end{array}$ & $\begin{array}{l}\text { Yield } \\
(\%)^{a}\end{array}$ & $\begin{array}{l}\text { M.p. } /{ }^{\circ} \mathrm{C} \\
\text { (solvent) }\end{array}$ & $\begin{array}{l}\text { Elemental analysis } \\
\text { (found/calculated) }\end{array}$ & $\delta\left(\mathrm{CDCl}_{3}, 90 \mathrm{MHz}\right)$ \\
\hline $\begin{array}{l}\text { TosNHz } \\
\mathbf{1 a}\end{array}$ & A & $\begin{array}{l}\mathrm{C}_{15} \mathrm{H}_{15} \mathrm{NO}_{4} \mathrm{~S} \\
(305.35)\end{array}$ & 97 & $\begin{array}{l}103.5-104 \\
\left(\mathrm{CH}_{2} \mathrm{Cl}_{2} / \mathrm{Et}_{2} \mathrm{O}\right. \\
1: 5)\end{array}$ & $\begin{array}{l}\mathrm{C}, 59.0 ; \mathrm{H}, 5.1 ; \mathrm{N}, 4.6 \\
\mathrm{C}, 59.0 ; \mathrm{H}, 5.0 ; \mathrm{N}, 4.6\end{array}$ & $\begin{array}{l}7.87(\mathrm{~d}, 2 \mathrm{H}, \mathrm{Tos} \mathrm{Ar} \mathrm{H}), 7.23-7.37(\text { complex } \\
\text { signal, ca. } 8 \mathrm{H}, \mathrm{Ar} \mathrm{H}+\mathrm{NH}), 5.08\left(\mathrm{~s}, 2 \mathrm{H}, \mathrm{CH}_{2}\right) \\
2.42\left(\mathrm{~s}, 3 \mathrm{H}, \mathrm{CH}_{3}\right)\end{array}$ \\
\hline $\begin{array}{l}\text { TrocNHBz } \\
\text { lb }\end{array}$ & $\mathbf{A}$ & $\begin{array}{l}\mathrm{C}_{10} \mathrm{H}_{8} \mathrm{Cl}_{3} \mathrm{NO}_{3} \\
(296.54)\end{array}$ & 99 & $\begin{array}{l}126.5-127.5 \\
\left(\mathrm{CH}_{2} \mathrm{Cl}_{2} / \mathrm{Et}_{2} \mathrm{O}\right. \\
10: 1)\end{array}$ & $\begin{array}{l}\mathrm{C}, 40.4 ; \mathrm{H}, 2.7 ; \mathrm{N}, 4.6 \\
\mathrm{C}, 40.5 ; \mathrm{H}, 2.7 ; \mathrm{N}, 4.7\end{array}$ & $\begin{array}{l}8.69(\mathrm{br} \mathrm{s}, \text { ca. } 1 \mathrm{H}, \mathrm{NH}), 7.38-7.70,7.87-7.97 \\
\text { (complex signal, } 5 \mathrm{H}, \mathrm{Ar} \mathrm{H}), 4.84\left(\mathrm{~s}, 2 \mathrm{H}, \mathrm{CH}_{2}\right)\end{array}$ \\
\hline $\begin{array}{l}\mathrm{Z}\left(\mathrm{NO}_{2}\right) \mathrm{NHBz} \\
\text { 1c }\end{array}$ & $\mathbf{A}$ & $\begin{array}{l}\mathrm{C}_{15} \mathrm{H}_{12} \mathrm{~N}_{2} \mathrm{O}_{5} \\
(300.27)\end{array}$ & 93 & $\begin{array}{l}155-155.5 \\
\left(\mathrm{CHCl}_{3}\right)\end{array}$ & $\begin{array}{l}\mathrm{C}, 60.1 ; \mathrm{H}, 4.0 ; \mathrm{N}, 9.3 \\
\mathrm{C}, 60.0 ; \mathrm{H}, 4.0 ; \mathrm{N}, 9.3\end{array}$ & \multirow{2}{*}{$\begin{array}{l}\left.\text { 8.21 [d, ca. } 3 \mathrm{H}, \mathrm{Z}\left(\mathrm{NO}_{2}\right) \mathrm{Ar} \mathrm{H}+\mathrm{NH}\right], 7.40- \\
7.90 \\
\text { (complex signal, } 7 \mathrm{H}, \operatorname{ar~H}), 5.36\left(\mathrm{~s}, 2 \mathrm{H}, \mathrm{CH}_{2}\right) \\
8.24,7.58(2 \mathrm{~d}, 4 \mathrm{H}, \mathrm{Ar} \mathrm{H}), 7.46(\mathrm{br} \mathrm{s}, \mathrm{ca} .1 \mathrm{H}, \\
\mathrm{NH}), 5.35\left[\mathrm{~s}, 2 \mathrm{H}, \mathrm{Z}\left(\mathrm{NO}_{2}\right) \mathrm{CH}_{2}\right] 4.82(\mathrm{~s}, 2 \mathrm{H}, \\
\left.\text { Troc } \mathrm{CH}_{2}\right)\end{array}$} \\
\hline $\begin{array}{l}\mathrm{Z}\left(\mathrm{NO}_{2}\right) \mathrm{NHT} \text { roc } \\
\text { 1d }\end{array}$ & A & $\begin{array}{l}\mathrm{C}_{11} \mathrm{H}_{9} \mathrm{Cl}_{3} \mathrm{~N}_{2} \mathrm{O}_{6} \\
(371.56)\end{array}$ & $6^{b}$ & $\begin{array}{l}149-150 \\
\text { (hexane/Et }{ }_{2} \mathrm{O} \\
10: 1 \text { ) }\end{array}$ & $\begin{array}{l}\mathrm{C}, 35.3 ; \mathrm{H}, 2.5 ; \mathrm{N}, 7.6 \\
\mathrm{C}, 35.6 ; \mathrm{H}, 2.4 ; \mathrm{N}, 7.5\end{array}$ & \\
\hline
\end{tabular}

${ }^{a}$ Crude. ${ }^{b}$ Obtained from crude Troc-NCO [prepared in low yield by reacting Troc- $\mathrm{NH}_{2}$ with $(\mathrm{COCl})_{2}$ ] and 4-nitrobenzyl alcohol according to method A. Chromatography $\left(\mathrm{CH}_{2} \mathrm{Cl}_{2}\right.$ /acetone, $9: 1$; silica) of the crude reaction mixture gave the pure compound.

Table 5 Selected properties of novel compounds: diacylamides (2a-1)

\begin{tabular}{|c|c|c|c|c|c|c|}
\hline $\begin{array}{l}\text { Compound } \\
\text { formula/no. }\end{array}$ & $\begin{array}{l}\text { Method of } \\
\text { preparation }\end{array}$ & $\begin{array}{l}\text { Compound } \\
\text { (M.W.) }\end{array}$ & $\begin{array}{l}\text { Yield } \\
(\%)^{a}\end{array}$ & $\begin{array}{l}\text { M.p. } /{ }^{\circ} \mathrm{C} \\
\text { (solvent) }\end{array}$ & $\begin{array}{l}\text { Elemental analysis } \\
\text { (found/calculated) }\end{array}$ & $\delta\left(\mathrm{CDCl}_{3}, 90 \mathrm{MHz}\right)$ \\
\hline $\begin{array}{l}\text { TrocN(Boc)Bzl } \\
2 \mathbf{a}\end{array}$ & B & $\begin{array}{l}\mathrm{C}_{15} \mathrm{H}_{18} \mathrm{Cl}_{3} \mathrm{NO}_{4} \\
(382.67)\end{array}$ & 93 & $\begin{array}{l}82.5-83.0 \\
\text { (ethyl acetate) }\end{array}$ & $\begin{array}{l}\mathrm{C}, 47.1 ; \mathrm{H}, 4.7 ; \mathrm{N}, 3.5 \\
\mathrm{C}, 47.1 ; \mathrm{H}, 4.7 ; \mathrm{N}, 3.7\end{array}$ & $\begin{array}{l}7.31(\mathrm{~s}, 5 \mathrm{H}, \mathrm{Ar} \mathrm{H}), 4.92(\mathrm{~s}, 2 \underset{\mathrm{H}}{\mathrm{H}}, \\
\left.\mathrm{CH}_{2} \mathrm{~N}\right), 4.81\left(\mathrm{~s}, 2 \mathrm{H}, \mathrm{CH}_{2} \mathrm{O}\right) 1.48(\mathrm{~s}, 9 \mathrm{H} \text {, } \\
\left.\mathrm{CH}_{3}\right)\end{array}$ \\
\hline $\begin{array}{l}\mathrm{Z}\left(\mathrm{NO}_{2}\right) \mathrm{N}(\mathrm{Boc}) \mathrm{Bzl} \\
\mathbf{2 b}\end{array}$ & B & $\begin{array}{l}\mathrm{C}_{20} \mathrm{H}_{22} \mathrm{~N}_{2} \mathrm{O}_{6} \\
(386.40)\end{array}$ & 82 & $\begin{array}{l}87.5-88.5 \\
\text { (ethyl acetate) }\end{array}$ & $\begin{array}{l}\mathrm{C}, 62.3 ; \mathrm{H}, 5.7 ; \mathrm{N}, 7.2 \\
\mathrm{C}, 62.2 ; \mathrm{H}, 5.7 ; \mathrm{N}, 7.2\end{array}$ & $\begin{array}{l}8.17,7.44\left[2 \mathrm{~d}, 4 \mathrm{H}, \mathrm{Z}\left(\mathrm{NO}_{2}\right) \mathrm{Ar} \mathrm{H}\right], 7.28(\mathrm{~s}, \\
5 \mathrm{H}, \mathrm{Ar} \mathrm{H}), 5.31\left(\mathrm{~s}, 2 \mathrm{H}, \mathrm{CH}_{2} \mathrm{O}\right), 4.88(\mathrm{~s}, 2 \\
\left.\mathrm{H}, \mathrm{CH}_{2} \mathrm{~N}\right), 1.44\left(\mathrm{~s}, 9 \mathrm{H}, \mathrm{CH}_{3}\right)\end{array}$ \\
\hline $\begin{array}{l}\operatorname{Tos}(\mathrm{N}(\mathrm{Bz}) \mathrm{Bzl} \\
2 \mathrm{c}\end{array}$ & C & $\begin{array}{l}\mathrm{C}_{21} \mathrm{H}_{19} \mathrm{NO}_{3} \mathrm{~S} \\
(365.45)\end{array}$ & 85 & $\begin{array}{l}105-106 \\
\text { (ethyl acetate) }\end{array}$ & $\begin{array}{l}\mathrm{C}, 69.2 ; \mathrm{H}, 5.3 ; \mathrm{N}, 3.8 \\
\mathrm{C}, 69.0 ; \mathrm{H}, 5.2 ; \mathrm{N}, 3.8\end{array}$ & $\begin{array}{l}\text { 7.16-7.66 (complex signal, 14 H, Ar H), } \\
4.99\left(\mathrm{~s}, 2 \mathrm{H}, \mathrm{CH}_{2} \mathrm{~N}\right), 2.41\left(\mathrm{~s}, 3 \mathrm{H}, \mathrm{CH}_{3}\right)\end{array}$ \\
\hline $\begin{array}{l}\text { TrocN(Tos)Bzl } \\
\text { 2d }\end{array}$ & $\mathrm{C}$ & $\begin{array}{l}\mathrm{C}_{17} \mathrm{H}_{16} \mathrm{Cl}_{3} \mathrm{NO}_{4} \mathrm{~S} \\
(436.74)\end{array}$ & 77 & $\begin{array}{l}118.5-119.5 \\
\text { (ethyl acetate) }\end{array}$ & $\begin{array}{l}\mathrm{C}, 46.7 ; \mathrm{H}, 3.8 ; \mathrm{N}, 3.2 \\
\mathrm{C}, 46.8 ; \mathrm{H}, 3.7 ; \mathrm{N}, 3.2\end{array}$ & $\begin{array}{l}\text { 7.67, 7.23(2d, } 4 \mathrm{H}, \mathrm{Tos} \mathrm{ArH}), 7.37(\mathrm{~s}, 5 \mathrm{H}, \\
\mathrm{Ar} \mathrm{H}), 5.13\left(\mathrm{~s}, 2 \mathrm{H}, \mathrm{CH}_{2} \mathrm{~N}\right), 4.70(\mathrm{~s}, 2 \mathrm{H} \text {, } \\
\left.\mathrm{CH}_{2} \mathrm{O}\right), 2.40\left(\mathrm{~s}, 3 \mathrm{H}, \mathrm{CH}_{3}\right)\end{array}$ \\
\hline $\begin{array}{l}\operatorname{TosN}(\mathrm{Z}) \mathrm{Bzl} \\
\mathbf{2 e}\end{array}$ & C & $\begin{array}{l}\mathrm{C}_{22} \mathrm{H}_{21} \mathrm{NO}_{4} \mathrm{~S} \\
(395.48)\end{array}$ & 73 & $\begin{array}{l}100.5-101.5 \\
\text { (light petroleum/ } \\
\mathrm{Et}_{2} \mathrm{O} \text { ) }\end{array}$ & $\begin{array}{l}\mathrm{C}, 66.8 ; \mathrm{H}, 5.3 ; \mathrm{N}, 3.5 \\
\mathrm{C}, 66.8 ; \mathrm{H}, 5.4 ; \mathrm{N}, 3.5\end{array}$ & $\begin{array}{l}7.50,7.09(2 \mathrm{~d}, 4 \mathrm{H}, \operatorname{Tos} \mathrm{Ar} \mathrm{H}), 7.33(\mathrm{~m}, 10 \\
\mathrm{H}, \mathrm{Ar} \mathrm{H}), 5.08,5.06\left(2 \mathrm{~s}, 4 \mathrm{H}, 2 \mathrm{CH}_{2}\right), 2.36 \\
\left(\mathrm{~s}, 3 \mathrm{H}, \mathrm{CH}_{3}\right)\end{array}$ \\
\hline $\begin{array}{l}\mathrm{Z}\left(\mathrm{NO}_{2}\right) \mathrm{N}(\mathrm{Tos}) \mathrm{Bzl} \\
\mathrm{2f}\end{array}$ & $\mathrm{C}$ & $\begin{array}{l}\mathrm{C}_{22} \mathrm{H}_{20} \mathrm{~N}_{2} \mathrm{O}_{6} \mathrm{~S} \\
(440.47)\end{array}$ & 81 & $\begin{array}{l}160-161 \\
\text { (ethyl acetate) }\end{array}$ & $\begin{array}{l}\mathrm{C}, 60.1 ; \mathrm{H}, 4.4 ; \mathrm{N}, 6.3 \\
\mathrm{C}, 60.0 ; \mathrm{H}, 4.6 ; \mathrm{N}, 6.4\end{array}$ & $\begin{array}{l}8.11,7.20\left[2 \mathrm{~d}, 4 \mathrm{H}, \mathrm{Z}\left(\mathrm{NO}_{2}\right) \mathrm{Ar} \mathrm{H}\right], 7.56, \\
7.16(2 \mathrm{~d}, 4 \mathrm{H}, \mathrm{Tos} \mathrm{Ar} \mathrm{H}), 7.35(\mathrm{~s}, 5 \mathrm{H}, \mathrm{Ar} \\
\mathrm{H}), 5.17\left(\mathrm{~s}, 2 \mathrm{H}, \mathrm{CH}_{2} \mathrm{O}\right), 5.09(\mathrm{~s}, 2 \mathrm{H}, \\
\left.\mathrm{CH}_{2} \mathrm{~N}\right), 2.39\left(\mathrm{~s}, 3 \mathrm{H}, \mathrm{CH}_{3}\right)\end{array}$ \\
\hline $\begin{array}{l}\mathrm{BzN}(\mathrm{Z}) \mathrm{Bzl} \\
\mathbf{2 g}\end{array}$ & D & $\begin{array}{l}\mathrm{C}_{22} \mathrm{H}_{19} \mathrm{NO}_{3} \\
(345.40)\end{array}$ & $98^{b}$ & $\begin{array}{l}65-65.5 \\
\text { (hexane/Et }{ }_{2} \mathrm{O} \text {, } \\
2: 1) \text { (twice) }\end{array}$ & $\begin{array}{l}\mathrm{C}, 76.5 ; \mathrm{H}, 5.5 ; \mathrm{N}, 4.0 \\
\mathrm{C}, 76.5 ; \mathrm{H}, 5.5 ; \mathrm{N}, 4.1\end{array}$ & $\begin{array}{l}\text { 6.80-6.94,7.07-7.56 (complex signal, } 15 \mathrm{H} \text {, } \\
\mathrm{Ar} \mathrm{H}), 5.03\left(\mathrm{~s}, 2 \mathrm{H}, \mathrm{CH}_{2} \mathrm{O}\right), 4.96(\mathrm{~s}, 2 \mathrm{H} \text {, } \\
\left.\mathrm{CH}_{2} \mathrm{~N}\right)\end{array}$ \\
\hline $\begin{array}{l}\text { TrocN(Bz)Bzl } \\
2 \mathrm{~h}\end{array}$ & D & $\begin{array}{l}\mathrm{C}_{17} \mathrm{H}_{14} \mathrm{Cl}_{3} \mathrm{NO}_{3} \\
(386.66)\end{array}$ & $94^{c}$ & $\begin{array}{l}36-36.5 \\
\text { (pentane } / \mathrm{Et}_{2} \mathrm{O} \\
20: 1)\end{array}$ & $\begin{array}{l}\text { C, } 53.0 ; \mathrm{H}, 3.7 ; \mathrm{N}, 3.6 \\
\mathrm{C}, 52.8 ; \mathrm{H}, 3.6 ; \mathrm{N}, 3.6\end{array}$ & $\begin{array}{l}7.247 .66(\text { complex signal, } 14 \mathrm{H}, \mathrm{Ar} \mathrm{H}) \text {, } \\
5.10\left(\mathrm{~s}, 2 \mathrm{H}, \mathrm{CH}_{2} \mathrm{O}\right), 4.62\left(\mathrm{~s}, 2 \mathrm{H}, \mathrm{CH}_{2} \mathrm{~N}\right)\end{array}$ \\
\hline $\begin{array}{l}\text { TrocN(Z)Bzl } \\
\mathbf{2 i}\end{array}$ & D & $\begin{array}{l}\mathrm{C}_{18} \mathrm{H}_{16} \mathrm{Cl}_{3} \mathrm{NO}_{4} \\
(416.69)\end{array}$ & 62 & $\begin{array}{l}39.5-40.5 \\
\text { (ethyl acetate/ } \\
\text { light petroleum) }\end{array}$ & $\begin{array}{l}\mathrm{C}, 51.7 ; \mathrm{H}, 4.0 ; \mathrm{N}, 3.4 \\
\mathrm{C}, 51.9 ; \mathrm{H}, 3.9 ; \mathrm{N}, 3.4\end{array}$ & $\begin{array}{l}7.34,7.28(2 \mathrm{~s}, 10 \mathrm{H}, \mathrm{Ar} \mathrm{H}), 5.27(\mathrm{~s}, 2 \mathrm{H}, \mathrm{Z} \\
\left.\mathrm{CH}_{2}\right), 4.97\left(\mathrm{~s}, 2 \mathrm{H}, \mathrm{CH}_{2} \mathrm{~N}\right), 4.82(\mathrm{~s}, 2 \mathrm{H}, \\
\left.\text { Troc } \mathrm{CH}_{2}\right)\end{array}$ \\
\hline $\begin{array}{l}\mathrm{Z}\left(\mathrm{NO}_{2}\right) \mathrm{N}(\mathrm{Bz}) \mathrm{Bzl} \\
\mathbf{2 j}\end{array}$ & D & $\begin{array}{l}\mathrm{C}_{22} \mathrm{H}_{18} \mathrm{~N}_{2} \mathrm{O}_{5} \\
(390.39)\end{array}$ & $71^{d}$ & $\begin{array}{l}96-96.5 \\
\left(\mathrm{CH}_{2} \mathrm{Cl}_{2} / \mathrm{Et}_{2} \mathrm{O}\right.\end{array}$ & $\begin{array}{l}\mathrm{C}, 67.7 ; \mathrm{H}, 4.8 ; \mathrm{N}, 7.1 \\
\mathrm{C}, 67.7 ; \mathrm{H}, 4.6 ; \mathrm{N}, 7.2\end{array}$ & $\begin{array}{l}8.02,6.90\left[2 \mathrm{~d}, 4 \mathrm{H}, \mathrm{Z}\left(\mathrm{NO}_{2}\right) \mathrm{Ar} \mathrm{H}\right], 7.28- \\
7.56(\text { complex signal, } 10 \mathrm{H}, \mathrm{Ar} \mathrm{H}), 5.06 \text {, } \\
5.05\left(2 \mathrm{~s}, 4 \mathrm{H}, \mathrm{CH}_{2} \mathrm{O}\right)\end{array}$ \\
\hline $\begin{array}{l}\mathrm{Z}\left(\mathrm{NO}_{2}\right) \mathrm{N}(\text { Troc }) \mathrm{Bzl} \\
\mathbf{2 k}\end{array}$ & D & $\begin{array}{l}\mathrm{C}_{18} \mathrm{H}_{15} \mathrm{Cl}_{3} \mathrm{~N}_{2} \mathrm{O}_{6} \\
(461.68)\end{array}$ & 95 & $\begin{array}{l}84-84.5 \\
\text { (hexane/Et } 2 \mathrm{O} \\
8: 1)\end{array}$ & $\begin{array}{l}\mathrm{C}, 46.7 ; \mathrm{H}, 3.3 ; \mathrm{N}, 6.0 \\
\mathrm{C}, 46.8 ; \mathrm{H}, 3.3 ; \mathrm{N}, 6.1\end{array}$ & $\begin{array}{l}8.19,7.48\left[2 \mathrm{~d}, 4 \mathrm{H}, \mathrm{Z}\left(\mathrm{NO}_{2}\right) \mathrm{Ar} \mathrm{H}\right], 7.32(\mathrm{~s}, \\
5 \mathrm{H}, \mathrm{Bzl} \mathrm{Ar} \mathrm{H}), 5.37\left[\mathrm{~s}, 2 \mathrm{H}, \mathrm{Z}\left(\mathrm{NO}_{2}\right) \mathrm{CH}_{2}\right] \\
5.01\left(\mathrm{~s}, 2 \mathrm{H}, \mathrm{CH}_{2} \mathrm{~N}\right), 4.85(\mathrm{~s}, 2 \mathrm{H} \text {, Troc } \\
\left.\mathrm{CH}_{2}\right)^{e}\end{array}$ \\
\hline $\begin{array}{l}\mathrm{Z}\left(\mathrm{NO}_{2}\right) \mathrm{N}(\mathrm{Z}) \mathrm{Bzl} \\
\mathbf{2 1}\end{array}$ & D & $\begin{array}{l}\mathrm{C}_{23} \mathrm{H}_{20} \mathrm{~N}_{2} \mathrm{O}_{6} \\
(420.42)\end{array}$ & 94 & $\begin{array}{l}96.5-97 \\
\left(\mathrm{CH}_{2} \mathrm{Cl}_{2} / \mathrm{Et}_{2} \mathrm{O}\right. \\
1: 20)\end{array}$ & $\begin{array}{l}\mathrm{C}, 65.9 ; \mathrm{H}, 4.8 ; \mathrm{N}, 6.7 \\
\mathrm{C}, 65.7 ; \mathrm{H}, 4.8 ; \mathrm{N}, 6.7\end{array}$ & $\begin{array}{l}8.11\left[\mathrm{~d}, 2 \mathrm{H}, \mathrm{Z}\left(\mathrm{NO}_{2}\right) \mathrm{Ar} \mathrm{H}\right], 7.22-7.39 \\
(\text { complex signal, } 12 \mathrm{H}, \mathrm{Ar} \mathrm{H}), 5.31[\mathrm{~s}, 2 \mathrm{H}, \\
\left.\mathrm{Z}\left(\mathrm{NO}_{2}\right) \mathrm{CH}_{2}\right], 5.25\left(\mathrm{~s}, 2 \mathrm{H}, \mathrm{ZCH}_{2}\right), 4.94(\mathrm{~s}, \\
\left.2 \mathrm{H}, \mathrm{CH}_{2} \mathrm{~N}\right)^{e}\end{array}$ \\
\hline
\end{tabular}

${ }^{a}$ Crude. ${ }^{b}$ Crude product containing $c a .25 \%$ of $O$-alkyl isomer $\left[\delta\left(\mathrm{CDCl}_{3}\right) 5.30\right.$ and $\left.5.16\left(2 \mathrm{~s}, \mathrm{CH}_{2} \mathrm{O}\right)\right]$. Recrystallization supplied the title compound. ' Yield of mixture. Repeated chromatography $\left(\mathrm{CH}_{2} \mathrm{Cl}_{2}\right.$; silica) of the crude Mitsunobu product containing $19 \%$ of $O$-benzyl isomer afforded a pure fraction of the $N$-benzyl analogue. The pure $O$-alkyl derivative gave $\delta\left(\mathrm{CDCl}_{3}\right) 5.37\left(\mathrm{~s}, \mathrm{CH}_{2} \mathrm{~N}\right)$ and $\left.4.76\left(\mathrm{~s}, \mathrm{Troc}^{\mathrm{C}} \mathrm{CH}_{2}\right)\right]$. ${ }^{d} \mathrm{Y}$ ield of mixture containing ca. $20 \%$ of $O$-alkylated isomer $\left[\delta\left(\mathrm{CDCl}_{3}\right) 5.33\right.$ and $\left.5.22\left(2 \mathrm{~s}, 2 \times \mathrm{CH}_{2} \mathrm{O}\right)\right]$. Recrystallization gave the pure title compound. ${ }^{e} 270 \mathrm{MHz}$.

Method D (compounds $2 \mathrm{~g}-1)$. Well dried $\mathrm{P}^{1} \mathrm{NHP}^{2}$ (1 eq.) was dissolved in dry tetrahydrofuran (THF) $\left(0.5 \mathrm{~mol} \mathrm{dm}^{-3}\right)$ together with $\mathrm{Ph}_{3} \mathrm{P}$ (1.2 eq.) and dry benzyl alcohol (1.1 eq.), and the resulting solution was cooled under argon at $0^{\circ} \mathrm{C}$. A solution of DEAD (1.3 eq.) in dry THF $\left(1.15 \mathrm{~mol} \mathrm{dm}{ }^{-3}\right)$ was then added dropwise with stirring over a period of $30 \mathrm{~min}$ giving a clear pale yellow mixture which was left overnight at room temperature with exclusion of moisture. The solvent was then evaporated at reduced pressure and the residual oil dissolved in a small volume of diethyl ether and again taken to dryness. This process was repeated three times. After suspending in an appropriate solvent the slurry was applied to a silica gel column. Elution 
with a mixture of light petroleum and diethyl ether $(2: 1)$ afforded $\mathrm{P}^{1} \mathrm{P}^{2} \mathrm{NBzl}$ in a yield as indicated in Table 5. Recrystallization was performed with the solvent listed.

Electrochemical Apparatus and Experimental Procedures. - A Hi-Tek potentiostat, type DT 2101, and a Hi-Tek wave generator, type PPR1, connected to a Philips recorder, type PM 8043, and to a three-electrode, home-built glass cell as illustrated elsewhere ${ }^{6}$ were used in the cyclic voltammetry experiments. The working electrode was a vitreous carbon disc (area $0.049 \mathrm{~cm}^{3}$ ) made by sealing a rod (Sigri Elektrographit $\mathrm{GmbH}$ ) into a glass support and grinding the face of the disc. The counter electrode was a platinum spiral and the reference electrode was a mercury pool separated from the working electrode by a Luggin capillary. Solutions of the substrate $(0.005$ $\mathrm{mol} \mathrm{dm}{ }^{-3}$ ) in dimethylformamide (DMF) containing $\mathrm{Et}_{4} \mathrm{NCl}$ $\left(0.1 \mathrm{~mol} \mathrm{dm}^{-3}\right)\left(\mathrm{Bu}_{4} \mathrm{NBF}_{4}\right.$ was used in the same concentration with the $\mathrm{Z}$ derivatives) as the supporting electrolyte. At the end of each experiment the potential of the mercury pool used as reference electrode was measured versus a standard calomel electrode (SCE). Between experiments the working electrode was repolished with alumina powder $(0.05 \mu \mathrm{m})$.

For the electrolyses only the potentiostat was used in connection with a conventional two-compartment, three-electrode, home-built cell of the type illustrated elsewhere ${ }^{6}$ but made of PTFE. The working electrode was a vitreous carbon disc (area $4.9 \mathrm{~cm}^{2}$ ) from Sigri Elektrographit $\mathrm{GmbH}$ placed in a holder so that only one face was exposed to the solution. The counter electrode was a platinum gauze (area $4.9 \mathrm{~cm}^{2}$ ) and the reference electrode was as above. The two compartments of the cell were separated by a Nafion membrane. A home-built integrator was used for occasional measurement of electric charges and a Fluke multimeter, type $8050 \mathrm{~A}$, for measurement of potentials. Both compartments of the cell were filled with acetonitrile containing $\mathrm{Et}_{4} \mathrm{NCl}\left(0.1 \mathrm{~mol} \mathrm{dm}^{-3}\right)$ as supporting electrolyte and methanol $(2 \%)$ or $\mathrm{Et}_{3} \mathrm{NHCl}\left(0.015 \mathrm{~mol} \mathrm{\textrm {dm } ^ { - 3 } )}\right.$ as a proton donor. An appropriate amount of the compound to be electrolysed was added to the cathodic compartment in order to obtain a solution with approximately $0.005 \mathrm{~mol} \mathrm{dm} \mathrm{dm}^{-3}$ and a cyclic voltammogram recorded, usually at a sweep rate of $100 \mathrm{mV} \mathrm{s}^{-1}$, in order to measure the peak potential of both reduction peaks. The exact concentration of substrate in the catholyte was determined by HPLC. This was deoxygenated in a fast stream of nitrogen, the potential adjusted to the value required, and the apparatus switched on. Unless otherwise stated, this potential was $50 \mathrm{mV}$ more negative than that corresponding to the first peak observed in the cyclic voltammogram. Throughout the experiment, readings of the intensity of the current passing through the solution and the charge measured by the integrator were eventually recorded in order to evalute the reaction progress. When the intensity of the current approached zero, a sample was drawn for HPLC in order to check if any starting material was still left and to determine the amount of product formed.

\section{Acknowledgements}

We wish to acknowledge the University of Minho, the Instituto Nacional de Investigação Cientifica, the Junta Nacional de Investigação Científica e Tecnológica (contract no. 87/96), the Swedish Natural Science Research Council and the National Swedish Board for Technical Development for financial support.

\section{References}

1 M. S. Gibson and R. W. Bradshaw, Angew. Chem., 1968, 80, 986 ; Angew. Chem., Int. Ed. Engl., 1968, 7, 919 (review).

2 S. Sugasawa and K. Abe, J. Pharm. Soc. Jpn., 1952, 72, 270; K. Abe, J. Pharm. Soc. Jpn., 1955, 75, 153; 159; 164; 168.

3 U. Ragnarsson and L. Grehn, Acc. Chem. Res., 1991, 24, 285 (review).

4 L. Grehn, K. Gunnarsson and U. Ragnarsson, Acta Chem. Scand, Ser. $B, 1987,41,18$

5 M. L. S. Almeida, L. Grehn and U. Ragnarsson, J. Chem. Soc., Perkin Trans. 1, 1988, 1905.

6 L. Grehn, K. Gunnarsson, H. L. S. Maia, M. I. Montenegro, L. Pedro and U. Ragnarsson, J. Chem. Res. $(S), 1988,399 ;(M), 1988,3081$.

7 M. A. Casadei, A. Gessner, A. Inesi, W. Jugelt and F. M. Moracci, J. Chem. Soc., Perkin Trans. 1, 1992, 2001.

8 H. L. S. Maia, M. J. Medeiros, M. I. Montenegro and D. Pletcher, J. Chem. Soc., Perkin Trans. 2, 1988, 409.

9 H. L. S. Maia, M. J. Medeiros, M. I. Montenegro and D. Pletcher, Port. Electrochim. Acta, 1988, 5, 187.

10 L. Grehn, H. L. S. Maia, L. S. Monteiro, M. I. Montenegro and U. Ragnarsson, J. Chem. Res. $(S), 1991,1944 ;(M), 1991,1501$.

11 M. D. Geraldo and M. J. Medeiros, Port. Electrochim. Acta, 1990, 8, 97.

12 M. F. Semmelhack and G. E. Heinsohn, J. Am. Chem. Soc., 1972,94, 5139; E. Kasafirek, Tetrahedron Lett., 1972, 20, 2021.

13 A. Ohta, Y. Inagawa and C. Mitsugi, J. Heterocycl. Chem., 1985, 22, 1643.

14 K. Takeda, K. Tsuboyama, M. Hoshino, M. Kishino and H. Ogura, Synthesis, 1987, 557

15 F. D. Chattaway, J. Chem. Soc., 1905, 87, 145

16 E. Beckmann, Ber. Dtsch. Chem. Ges., 1890, 23, 3331.

17 E. Fujita, Y. Nagao, K. Seno, S. Takao, T. Miyasaka, M. Kimura and W. H. Watson, J. Chem. Soc., Perkin Trans. 1, 1981, 914

18 L. Grehn, M. L. S. Almeida and U. Ragnarsson, Synthesis, 1988, 992.

19 L. Grehn and U. Ragnarsson, Collect. Czech. Chem. Commun., 1988, 53, 2778.

Paper 2/05275J

Received 1st October 1992 Accepted 10th November 1992 